\author{
Н. Й. РАДІОНОВА, \\ кандидат економічних наук, \\ доџент кафедри обліку і аудиту, \\ Київський національний університет \\ технологій та дизайну
}

\title{
Загальні аспекти управління виробничими затратами українських підприємств в умовах економічної кризи
}

У статті розалянуті питання управління виробничими затратами украйнських підприємств в кризових умовах. Зазначено чинники, які мають негативний вплив на господарську діяльність вітчизняних підприсмств в сучасних умовах. Показаний механізм управління затратами підприсмства з метою їх оптимізації. Розкрито характерні недоліки існуючих систем управління затратами та показано наслідки цих недоліків для підприсмств.

Ключові слова: управління затратами, виробничі затрати, класифікація затрат, скорочення затрат, підприсмство.

Постановка проблеми та ії зв'язок із важливими науковими та практичними завданнями. 3 розвитком економіки та зростанням кількості суб' єктів господарювання важливою умовою виживання підприємства у ринковому середовищі є раціональне управління виробничими затратами. Раціонально побудована система управління затратами на підприємстві дозволяє зменшити собівартість продукції (послуг), що виготовляється (надаються), оптимізувати рівень затрат безпосередньо на організацію бізнесу і на підставі цього підвищити рівень фінансових результатів.

3 метою дослідження ефективного управління виробничими затратами на вітчизняних підприємствах необхідно враховувати особливості управління в умовах економічної кризи.

Аналіз останніх досліджень і публлікацій. Загальні питання управління виробничими затратами підприємства знайшли висвітлення у працях вітчизняних та зарубіжних науковців-економістів: Т. Гринько [1], К. Столпової [1], М. Скрипник [2], Н. Хаймьонової [3], К. Чичуліної [4], М. Чумаченко [5], І. Білоусової [5], Т. Яровенко [6], А. Довгої [6], В. Остряніної [6], А. Ясінської [7] та інших.

Вітчизняні та зарубіжні автори зробили значний внесок у вирішення проблем, що розглядаються в статті, проте не вичерпали ї. Широке коло питань теоретикометодологічного і прикладного характеру, пов'язаних із управлінням виробничими затратами на підприємствах в умовах економічної кризи, не отримало досить повного й однозначного вирішення і потребує подальшого дослідження.

Метою дослідження $\epsilon$ аналіз різних підходів до управління виробничими затратами українських підприємств в умовах економічної кризи.

Виклад основного матеріалу дослідження. Складність управління затратами виробництва полягає в необхідності поєднання значної кількості даних щодо господарської діяльності підприємства в єдину систему економічного управління, яка включає сукупність принципів, методів, форм і прийомів управління. Крім того, потрібно чітко виділити предмет та об' єкти управління в умовах об' єктивно існуючих невизначеності та ризиків, спричинених нестабільністю економічних умов в Україні, жорсткою загальною конкуренцією та значною кон'юнктурною залежністю від уподобань споживачів. Йдеться про функціонування на підприємстві системного економічного механізму, спрямованого на раціональне зниження наявних виробничих затрат. Загальні особливості управління виробничими затратами передбачають виконання всіх дій, які реалізуються під час управління будь-яким об' єктом, тобто розроблення і реалізацію рішень, а також контроль за їх виконанням. Такі дії реалізуються через елементи управлінського циклу: прогнозування, планування, організацію, мотивацію, облік та аналіз [5].

(с) Н. Й. Радіонова, 2017 
Специфікою управління виробничими затратами на вітчизняних підприємствах $\epsilon$ орієнтація на ситуаційно-ресурсний (аналітичний підхід до кожного ресурсу підприємства в рамках динамічних характеристик поточних ситуацій) та ресурснофункціональний (моделювання розвитку підприємства на основі кількісного й якісного розширення простору ресурсів і подолання супутньої невідповідності інтересів окремих функщіональних областей) підходи.

Криза мікроекономічної системи, як правило, не виникає спонтанно, вона має свої причини (етіологію) та зовнішні прояви (ознаки). Причина появи кризових явищ у діяльності суб' єктів господарювання криється в самому ринковому господарстві, у постійній зміні ринкових орієнтацій споживачів, у невизначеності економічної поведінки контрагентів підприємства, у необхідності постійного корегування основних елементів та функціональних підсистем самого підприємства 3 метою забезпечення адекватності вхідним та вихідним параметрам розвитку системи в цілому. Суттєвим фактором є несприятливий вплив зовнішнього середовища. Первинним зовнішнім проявом кризи на мікрорівні $є$ формування стійкої тенденції руху поточних затрат у бік збільшення, а обсягу діяльності, доходів та прибутку - у бік зменшення [2].

Зрозуміло, що в умовах кризи багато українських підприємств намагаються просто вижити.

Доцільно виділити негативні чинники впливу на господарську діяльність вітчизняних підприємств:

- втрата зовнішньоекономічних зв'язків із контрагентами ближнього зарубіжжя;

- неможливість налагодження тривалих зовнішньоекономічних зв'язків із контрагентами інших країн через нестабільну політичну ситуацію у країні;

- суттєве подорожчання енергетичних і матеріальних ресурсів у складі собівартості продукції;

- обмеженість внутрішнього ринку споживання промислової продукції;

-

- обмеженість бази стимулювання ефективності виробничої діяльності підприємства [1].

Для забезпечення ефективного менеджменту на підприсмстві необхідно організувати управління виробничими затратами в різних аспектах, зокрема за технологіями (звичайні, інтенсивні тощо), центрами відповідальності, видами продукції, за відповідальними особами, що дозволяє всебічно аналізувати рівень затрат, визначати іх відповідність встановленим нормам і на цій основі розробляти власну політику управління виробничими затратами, застосовуючи ефективні методи і механізми на всіх рівнях управління. В сучасних умовах процес управління затратами обумовлюється господарською та фінансовою самостійністю підприємств. Господарська самостійність полягас у можливостях вибору організаційної форми підприємства, виду діяльності, виробничої програми, партнерів з бізнесу, внаслідок чого суттєво зростає відповідальність керівників за прийняті рішення.

Ефективність функціонування підприємства багато в чому залежить від раціонального використання всіх видів ресурсів, що обумовлює необхідність поступового переходу до єдиної системи управління виробничими затратами.

Перевагами впровадження такої системи можна вважати забезпечення виробництва конкурентоспроможною продукцією завдяки зниженню затрат і цін; наявність якісної та достовірної інформації про собівартість окремих видів продукції та їх позиції на ринку в порівнянні з продукцією інших виробників; можливість використання гнучкого ціноутворення; надання об'єктивних даних для упорядкування бюджету підприємства; можливість аналізу і оцінки діяльності кожного підрозділу підприємства; прийняття ефективних та обгрунтованих управлінських рішень.

Система управління затратами підприємства - це комплекс пов' язаних елементів та відносин у системі управління підприємством, які завдяки раціональному використанню його ресурсів забезпечують його стабільне функціонування. Кожний окремий елемент виконує відповідні функції й завдання систем управління затратами [1].

Управління затратами передбачає систематичний моніторинг та аналіз їх поведінки під дією як внутрішніх, так і зовнішніх чинників, прийняття рішень щодо покращення структури собівартості продукції тощо (рис. 1) [3]. 
Одним з найпопулярніших заходів є зниження затрат, коли підприємства змушені йти шляхом економії [4]. Успішні підприємства регулярно займаються переглядом своїх затрат, а в умовах кризи це набуває вирішального значення. До питань скорочення затрат потрібно підходити дуже обмірковано, адже надмірне захоплення економією не менш небезпечне, ніж бажання залишити все, як $€$.

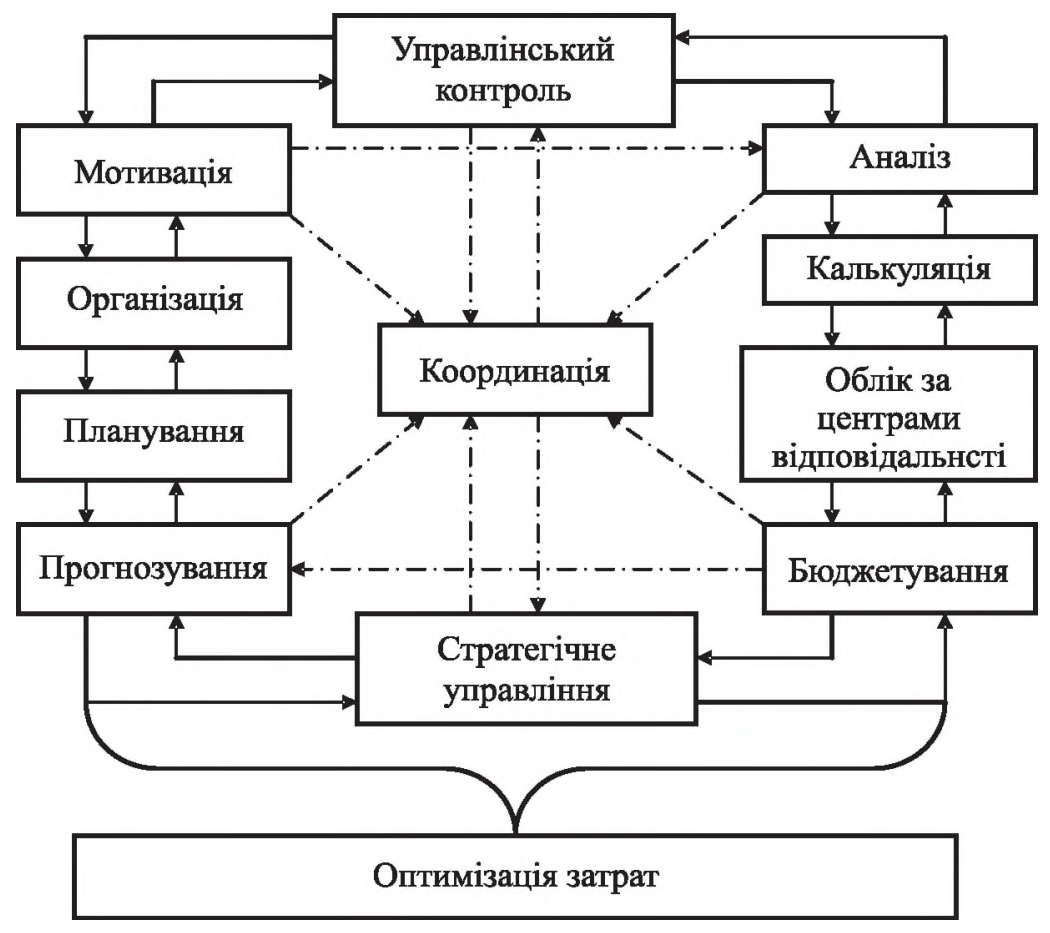

Рис. 1. Механізм управління затратами підприємства Джерело: [3]

Більшість існуючих систем управління затратами має низку недоліків, основні 3 яких наведено у табл. 1.

Таблиця 1

Характерні недоліки систем управління затратами

\begin{tabular}{|c|c|}
\hline $\begin{array}{c}\text { Недоліки діючих } \\
\text { систем управління затратами }\end{array}$ & Наслідки недоліків дінчих систем \\
\hline 1 & 2 \\
\hline $\begin{array}{l}\text { Відсутні порядок регулювання і урахування } \\
\text { сумарних затрат та їх структури на стадіях } \\
\text { життєвого циклу продукції. }\end{array}$ & $\begin{array}{l}\text { Неможливість цілеспрямовано впливати на } \\
\text { оптимізацію та зниження сумарних затрат }\end{array}$ \\
\hline $\begin{array}{l}\text { Здійснюсться лише автономне управління } \\
\text { комплексом затрат за господарськими оди- } \\
\text { ницями (ланками), але не за виробами. }\end{array}$ & $\begin{array}{l}\text { Зниження затрат однієї із ланок може при- } \\
\text { звести до збільшення сумарних затрат; } \\
\text { зменшується можливість планування затрат. }\end{array}$ \\
\hline $\begin{array}{l}\text { Управління реалізується через план, сфор- } \\
\text { мований за базовими затратами, згідно } 3 \\
\text { критеріями оцінки діяльності конкретної } \\
\text { господарської ланки. }\end{array}$ & $\begin{array}{l}\text { Підприємства орієнтуються на виконання } \\
\text { плану, не враховуючи реальні можливості } \\
\text { зниження затрат за виробами та досягнення } \\
\text { науково-технічного прогресу. } \\
\end{array}$ \\
\hline $\begin{array}{l}\text { На кожній наступній стадії (на кожному } \\
\text { етапі) не беруться до уваги економічні } \\
\text { розрахунки затрат, виконані на попередніх } \\
\text { стадіях. }\end{array}$ & $\begin{array}{l}\text { Можливе завищення сумарних затрат; } \\
\text { неточно оцінюється та врахову сться } \\
\text { внесок учасників нововведень у загальні } \\
\text { результати; неточно оцінюються результати } \\
\text { розвитку. }\end{array}$ \\
\hline
\end{tabular}




\begin{tabular}{|c|c|}
\hline & Продовэсення табл. 1 \\
\hline 1 & 2 \\
\hline $\begin{array}{l}\text { Відсутня завершена система поетапного } \\
\text { проекту вання; резу льтати прогнозу не є } \\
\text { обов'язковими для наступних стадій. }\end{array}$ & $\begin{array}{l}\text { Затягується освоєння економічних } \\
\text { параметрів виробу через відсутність } \\
\text { послідовності економічних показників } \\
\text { проекту за стадіями життєвого циклу } \\
\text { виробу. }\end{array}$ \\
\hline $\begin{array}{l}\text { При атестації економічного рівня та } \\
\text { якості продукції майже не враховуються } \\
\text { економічні параметри. }\end{array}$ & $\begin{array}{l}\text { Знижується об'єктивність та ефективність } \\
\text { оцінки при атестації продукції. }\end{array}$ \\
\hline $\begin{array}{l}\text { Відсутня стратегія зниження затрат учас- } \\
\text { никами процесу розвитку; не встановлено } \\
\text { контрольні точки оцінки доцільності } \\
\text { подальшого здійснення затрат. }\end{array}$ & $\begin{array}{l}\text { Допускаються збільшення затрат на повний } \\
\text { життєвий цикл, неточності у визначенні } \\
\text { планових завдань зі зниження затрат; } \\
\text { можливість розроблення проектів не } 3 \\
\text { максимальною ефективністю. }\end{array}$ \\
\hline $\begin{array}{l}\text { Не визначена структура управління затра- } \\
\text { тами на виріб; діюча система управління } \\
\text { якістю не наповнена економічним змістом. }\end{array}$ & $\begin{array}{l}\text { Допускаються втрати ефективності під час } \\
\text { зміни стадій життєвого циклу; знижується } \\
\text { ефективність у правління затратами у } \\
\text { виробництві. }\end{array}$ \\
\hline
\end{tabular}

Джерело: [2]

Захопившись питаннями оптимізації затрат, багато керівників приймають рішення, які не спрямовані на підвищення ефективності діяльності підприємства в перспективі. Наприклад, скорочують затрати, які є життєво важливими для підприємства. Застосування стратегії тотального зниження затрат призводить до того, що в намаганні якомога більше зекономити керівництво підприємства починають “зрізати” цілі статті затрат, не вникаючи в те, який результат для бізнесу вони приносять.

Наприклад, знижуючи затрати на рекламу керівник повинен розуміти, що скорочувати їх можна тільки в тому випадку, якшо підприємство знайде інші, більш дешеві методи реклами, просування своєї продукції, інформування покупшів, споживачів, партнерів про свої бізнес-пропозиції.

Або, скоротивши затрати на технічне обслуговування і ремонт основних засобів, потрібно розуміти, що скорочення цієї статті затрат збільшує виробничі ризики, ставлячи “під питання" самі виробничі прочеси.

Такі непродумані дії можуть призвести не до поліпшення ситуації, а, навпаки, до iї погіршення.

Іншою поширеною помилкою $є$ надмірне скорочення персоналу або серйозне урізання заробітної плати. Як правило, у відділі залишають кілька співробітників, в обов'язки яких входять функшіі, які раніше виконувалися цілим відділом. Крім того, ім ще й зарплата "урізається". Результат такої політики відомий - трудовіддача знижується, через великий обсяг робіт частіше допускаються помилки і кваліфіковані співробітники починають шукати собі роботу на іншому підприємстві [5].

Також хибною є стратегія, коли з метою зниження затрат підприємство свідомо знижує якість виробленої продукції, що дає можливість знизити ії ціну. Але практика показує, що такі кроки значно знижують шанси підприємства серед конкурентів, а отже і ефективність його діяльності.

Почати оптимізацію затрат необхідно з аналізу роботи підприємства: визначити, в якому стані наразі знаходиться підприємство, тобто проаналізувати логістику закупівель, виробництва, продажу, внутрішніх переміщень матеріалів, виявити “вузькі місця" в системі управління запасами, з ясувати, які затрати і в якому місці виникають, якою має бути їх оптимальна величина [7].

Для здійснення ефективного аналізу доцільно застосувати розроблену стратегію.

Необхідно описати бізнес-процеси, що існують на підприємстві. Це дасть можливість: оцінити їх ефективність і визначити проблемні місця (дублювання відповідальності, документів або, навпаки, відсутність необхідних дій). В умовах 
кризи, на відміну від “традиційної” роботи з оптимізації бізнес-процесів, важливим стає чинник часу: зміни повинні бути проведені швидко. Тому доцільно не розглядати діяльність підприємства як комплексну систему, а виділити найбільш критичні бізнес-процеси, оптимізація яких може дати найбільший ефект, i займатися тілыки цією групою процесів.

Далі слід проаналізувати модель фактичних і побудувати діаграми вдосконалених бізнес-процесів.

На наступному етапі потрібно оптимізувати роботу персоналу. Для цього потрібно:

1) переглянути існуючу організаційну структуру підприємства з точки зору якісної організації бізнес-процесів;

2) визначити підрозділи і посади, функції і відповідальність яких дублюються;

3) прописати посадові інструкції для персоналу, виключаючи дублювання функцій і посадових обов'язків;

4) звільнити співробітників, робота яких малоефективна, при цьому спрямувавши зусилля на мотивацію висококваліфікованих фахівців, втрата яких може значно знизити результати роботи підприємства; той персонал, який має значний вплив на якість продукції, конкурентоспроможність виробництва, необхідно обов'язково зберегти.

У періоди кризи потрібно посилити роботу з клієнтами, а саме [6]:

1) утримати тих клієнтів, які приносять підприємству максимальний результат (за правилом Парето, $20 \%$ клієнтів приносять $80 \%$ результату), сконцентрувавши зусилля на важливих для них параметрах товарів та обслуговування і вибудувавши для цього бізнес-процеси підприсмства так, шоб вони були максимально оріснтовані на якісне задоволення їхніх вимог;

2) зберегти рівень затрат на рекламу, яка “добре працює”, на ті перевірені канали комунікацій зі споживачами, які довели свою ефективність;

3) використовувати дешевші і умовно безкоштовні методи реклами, просування, інформування покупців, споживачів, партнерів про свої бізнес-пропозиції;

4) забезпечити повне завантаження виробництва, яке є основною умовою зниження умовно постійних затрат; якщо це неможливо (наприклад, через недостатній попит на продукцію підприсмства), слід, навпаки, “згорнути" його (законсервувати частину виробничих потужностей, передати в оренду частину основних засобів тошо);

5) переглянути існуючу стратегію роботи з постачальниками.

При цьому можна використовувати такі стратегії:

- підвищення ефективності взаємодії і скорочення затрат шляхом скорочення кількості постачальників;

- збільшення кількості постачальників (з метою підстрахуватися, якщо з одним iз постачальників виникнуть складнощі).

Висновки Розробляючи систему оптимізації затрат, потрібно дуже грамотно підходити до застосовування режиму жорсткої економії, оскільки помилки в цьому питанні можуть привести до ще більш негативних наслідків. Професійні керівники, розробляючи заходи зі скорочення затрат, повинні приймати стратегічно правильні рішення, які не приноситимуть нових проблем: збільшення виробничих ризиків (наприклад, через відмову від модернізації основних засобів), зменшення товарообороту (наприклад, через відмову від рекламних заходів), зниження якості продукції (наприклад, через використання більш дешевих матеріалів та сировини), зниження трудовіддачі працівників (через зменшення мотивації, надмірне скорочення персоналу або серйозне урізання заробітної плати) тощо.

Кожному підприємству важливо проаналізувати свою діяльність та виділити критичні, 3 точки зору виробничих затрат, бізнес-процеси, вдосконаленням яких слід приділити увагу в першу чергу. Свропейська практика показує, що позитивний ефект дає посилення роботи 3 клієнтами та постачальниками, використання більш дешевих методів просування продукції, перегляд кадрової політики з індивідуальною мотивацією працівників в залежності від ефективності їх роботи тощо.

Високопрофесійні керівники розуміють, що економічна нестабільність - явище не вічне. Тому, ще перебуваючи в стані кризи, керівникам підприємств вже потрібно думати про подальше зростання. 


\section{Список використаних джерел}

1. Гринько Т. В., Столпова К. В. Обгрунтування стратегії зниження затрат підприємства [Електронний ресурc]. URL: http://www.zgia.zp.ua/gazeta/evzdia_6_131.pdf

2. Скрипник М. I. Організація обліку витрат у розрізі центрів витрат та центрів відповідальності // Облік і фінанси АПК. 2011. № 1. С. 46-49.

3. Хаймьонова Н. С., Головацька С. І. Методичний інструментарій бюджетування у системі управління затратами підприємства // Вісник Львівської комерційної академії. Серія: Економіка. 2015. Вип. 47. С. 42-46.

4. Чичуліна К. В. Удосконалення системи управління затратами на сільськогосподарських підприємствах [Електронний ресурс] // Ефективна економіка. 2015. № 5. URL: http://www.economy.nayka.com.ua/?op=1\&z=4062

5. Чумаченко М., Білоусова І. П.: П(С)БО 16 "Витрати" перешкоджають роботі на підприємстві // Бухгалтерський облік і аудит. 2009. № 10. С. 3-10.

6. Яровенко Т. С., Довга А. О., Остряніна В. Е. Шляхи та методи оптимізації витрат підприємствау ринкових умовах // Вісник Дніпропетровського університету. Серія: Економіка. 2013. Т. 21. Вип. 7(2). С. 181-188.

7. Ясінсыка А. І. Сутність управління затратами на вітчизняних підприємствах [Електронний ресурс] // Національний університет “Львівська політехніка". 2007. URL: http://vlp.com.ua/fiIes/54.pdf

Н. Й. РАДИОНОВА,

кандидат экономических наук,

дочент кафедры учета и аудита,

Киевский национальный университет

технологий и дизайна

\section{Особенности управления производственными затратами украинских предприятий в условиях экономического кризиса}

В статье рассмотрены вопросы управления производственными затратами украинских предприятий в кризисных условиях. Указаны факторы, которые негативно влияют на хозяйственную деятельность отечественных предприятий в современных условиях. Показан механизм управления затратами предприятия с иелью их оптимизации. Раскрыты характерные недостатки существующих систем управления затратами и показаны последствия этих недостатков для предприятий.

Ключевые слова: управление затратами, производственные затраты, классификация затрат, сокращение затрат, предприятие.

\section{N. Y. RADIONOVA, PhD (Economics), Associate Professor of Accounting and Audit Department, Kyiv National University for Technology and Design}

\section{Peculiarities of Production Cost Management in Ukrainian Companies in the Context of Economic Crisis}

A vital condition for company's survival in the market environment is rational management of production costs. The purpose of the study is to analyze various approaches to production costs management in Ukrainian companies in the conditions of economic crisis. Factors that affect business operation of domestic enterprises in times of economic crisis are outlined. The mechanism for production costs management at company level is shown; most common defects and mistakes in cost management systems are highlighted. The strategy for effective analysis of company costs is proposed, which covers the following phases: describe business processes existing in a company; build the model of actual business processes, analyze and improve it; optimize the work of personnel; improve the contacts with clients and suppliers (a vital step in the crisis conditions). It is argued that whenever a system for 
cost optimization is built, the right approach to austerity measures will be required, because a mistake in this matter can aggravate the company performance. Company managers responsible for measures on cost reduction need to take strategically right decisions that won't trigger new problems for a company: the grown production risks (resulting from withdrawal from modernization of fixed assets), the reduced turnover (resulting from use of cheaper inputs), the reduced labor output (due to the decreased motivation, excessive downsizing of personnel or pay cuts).

Keywords: cost management, production costs, cost classification, cost reduction, enterprise.

Посилання на статтю:

Радіонова Н. Й. Загальні аспекти управління виробничими затратами українських підприємств в умовах економічної кризи // Науковий вісник Національної академії статистики, обліку та аудиту: зб. наук. праць. 2017. №1-2. С. 77-83. 